\title{
Management of Insect Vectors of Viruses in Tomato Plants Using Different Densities of Yellow Traps
}

\author{
Eduardo Domingos Grecco, Dirceu Pratissoli, Hugo Bolsoni Zago, Débora Ferreira Melo Fragoso and José \\ Romário Carvalho \\ Department of Plant Production, Center of Agricultural Sciences and Enengineering (CCAE), Universidade Federal do Espirito \\ Santo (CCA-UFES), Alegre, Espirito Santo, Brazil
}

\begin{abstract}
The initial phase of tomato is critical to the infestation of insect vectors of viruses. Therefore, this study aimed to test the use of yellow card traps around the crop to manage insect vectors of viruses and test the best density of traps/tomato plants. Yellow card traps were placed on the border of the crop plot to capture adult insect vectors. Density of trap/tomato plant was assessed in 10 blocks at the following levels: $1 / 25 ; 1 / 50 ; 1 / 75 ; 1 / 100 ; 1 / 125 ; 1 / 150$. The monitoring was carried out in $1 \%$ of the crop during 60 days in 2011 and 2012 crop. The evaluated systems were Conventional and Phytosanitary Pest Management (PPM). During 2011 season the Conventional system received 14 insecticide applications whereas only 6 insecticide applications were made on the PPM, representing a reduction of $133 \%$. In 2012, the crop under Conventional system was subjected to 15 applications of insecticides, over 8 on PPM, with a reduction of $87.5 \%$. The PPM allowed a $90 \%$ reduction in application cost for this insects, obtaining a reduction of $\mathrm{R} \$ 1,345.00 / \mathrm{ha}$. The highest density was 60 plants/trap. We can conclude that the yellow card traps in tomato crop decreased infestations of insect vectors of viruses.
\end{abstract}

Key words: Viruses vectors, Solanum lycopersicum, yellow card trap.

\section{Introduction}

The tomato (Lycopersicon esculentum Miller), is a solanaceous with socioeconomic benefits, but the implementation of this crop is considered as a high risk one due the occurrence of pests and diseases throughout the cycle $[1,2]$.

Large leaf exchange area and staggered tomatoes planting in nearby areas are considered the main factors to insect vectors of viruses onset. The formation of an ideal microclimate and constant availability of food for long periods allows a concurrency of several generations in high population levels of insect vectors of viruses in tomato [3, 4].

The first stage of crop development, which lasts up to 60 days, is considered critical to virus vectors. These insects are classified as aphids, Myzus persicae

Corresponding author: Débora Ferreira Melo Fragoso, doctor, research fields: entomology, viruses vectors, solanum lycopersicum and yellow card trap.
Sulzer Macrosiphum euphorbiae Thomas (Homoptera: Aphididae), which transmit four types of viruses, tomato yellow top and tomato mosaic, the "Y" and virus yellow botton. The insects known as thrips, Frankliniella schultzei Trybom and Thrips palmi Karny (Thysanoptera: Thripidae), also fit in this category, responsible for transmitting the virus complex called tomato spotted wilt. The whitefly, Bemisia tabaci Gennadius (Hemiptera: Aleyrodidae), is another viruses transmitter, which is responsible for spreading four viruses, the most common cause of tomato golden mosaic and Tospoviruses. These viruses are considered limiting factors because infected plants cannot produce fruits, or when produced, they do not meet market requirements $[5,6]$.

In any pest management program it is essential to monitor arthropod pests and pests which do not occur in an agricultural system, since they facilitate decision making concerning the introduction of control measures. Therefore, it is important to use colored 
yellow card traps and their correct distribution in the planting area.

The objective of this research was to test the use of yellow card traps surrounding the crop to manage insect vectors and assess the best density of trap/tomato plants.

\section{Materials and Methods}

The experiments were conducted by the Nucleus of Scientific and Technological Development in Phytosanitary Management of Pests and Diseases (NUDEMAFI), Federal University of Espírito Santo (CCA-UFES), in 2011 and 2012 harvests in Cachoeiro de Itapemirim, geographical coordinates $20^{\circ} 50^{\prime} 56^{\prime \prime}$ south and $41^{\circ} 06^{\prime} 46^{\prime \prime}$ west (Distrito Córrego dos Monos)—Espírito Santo in tomato plantations treated with Conventional and Phytosanitary Pest Management (PPM). The experiment was conducted during May-September of both crop the variety used was Ibatã (recommended for the region). The cultivation, transplanting, staking, tying, designated rig and thinning were performed following crop recommendations [7].

We adopted the guidance system with two stems per plant in vertical staking, the most used by producers of staked tomatoes in the State of Espírito Santo. This method was based on the conduction of plants on bamboo stakes on which plants were tied every 7 days. We used a $1.3 \times 0.6 \mathrm{~m}$ spacing (lines $\times$ plants).

Systems management reviews. The systems evaluated were: (1) Phytosanitary Pest Management (PPM) [8] and adapted monitoring pests [9] (Table 1) and in decision making to the application of insecticides based on the level of infestation in the field. (2) Conventional (producer), who adopted calendar sprays drawn up by producers where applications started seven days after transplanting and continued to be held twice a week regardless of the level of pest infestation in the field (Table 2). Pesticides that producers used to control insect vectors of viruses were used.

Biocontrol ${ }^{\circledR}$ yellow card traps $(100 \mathrm{~cm} \times 30 \mathrm{~cm})$ with adhesive glue were placed around the tomato PPM for adults insects vectors of viruses were captured and did not cause damage to tomato crop. These traps were changed every 20 days because they lie with the area of adhesive glue without empty spaces for capturing or young adults because of the loss of the chemical structure of the adhesive insects, because the field receives solar rays that degrade the adhesive, making traps less sticky.

The experiment was conducted in a plot with 2,000 plants consisting in 4 repetitions. The monitoring reviews were made 7 days after planting, in $1 \%$ of the crop. For each repetition 1 random spot was assessed

Table 1 Pest, sampling methods and action level adopted in the Phytosanitary Pest Management (PPM) system [9].

\begin{tabular}{|c|c|c|c|}
\hline Pest Vector & & Sampling Method & Action level \\
\hline Vectors & $\begin{array}{l}\text { Whitefly_Bemisia tabaci (Tospoviruses) } \\
\text { Aphids_Mysus perssicae and } \\
\quad \text { Macrosiphum euphorbiae (Mosaics) } \\
\text { Thrips_Frankliniella schultzei (winter cropping tomato) }\end{array}$ & $\begin{array}{l}\text { Knock rod in PVC boxes } \\
\text { with blue background }\end{array}$ & $\begin{array}{l}1 \text { vector by rod in mean } \\
\text { and/or } 0.5 \text { thrips/rod in } \\
\text { tomato }\end{array}$ \\
\hline
\end{tabular}

Table 2 Insecticides used by producers in Phytosanitary Pest Management (PPM) and conventional.

\begin{tabular}{lllll}
\hline Product & Active Ingredient & MAPA Register & Chemical & Dose $\mathrm{mL} / \mathrm{ha}$ \\
\hline Actara 250 WG & Thiamethoxam & 10,098 & Neonicotinoid & $500-1,000$ \\
Platinum Neo & Thiamethoxam + & 5,110 & Neonicotinoid + & $50-100$ \\
Lambda-cialotrina & Pyrethoid & Neonicotinoid + & Pyrethoid \\
Connect & Imidacloprid + & 4,804 & $500-1,000$ & $500-600$ \\
Oberon & Beta-ciflutrin & 1,706 & Keto-enol & $250-400$ \\
Mospilan & Espiromesifen & 10,498 & Neonicotinoid & \\
\hline
\end{tabular}


with 5 plants in a row, being evaluated the top of the plants [10]. These evaluations were performed making knock rod in a plastic tray $(40 \mathrm{~cm} \times 20 \mathrm{~cm} \times 10 \mathrm{~cm})$ of blue color, which accounted adult insects present and alive. The index for application of insecticide, if necessary, a first vector is rod. The data were analyzed through Shapiro-Wilk test of normality and absence by non-parametric Mann-Whitney $P \leq 0.05$.

The density experiment of yellow card trap/plants was in an area with 8,000 plants, the following densities were used: $1 / 25(=0.04) ; 1 / 50(=0.02) ; 1 / 75$ $(=0.13) ; 1 / 100(=0.01) ; 1 / 125(=0.008) ; 1 / 150(=$ 0.007) trap/plants. As control treatment, yellow traps were not used and the experimental unit was composed of $1,000(=0.001)$ tomato plants over conventional planting. The experiment was conducted in 10 blocks, and the evaluations were done twice a week for 60 days, which is the most critical period for viruses in tomato. Yellow card traps $(100 \mathrm{~cm} \times 30 \mathrm{~cm})$ were distributed equidistantly among the plants according to its scope and so they did not interfere one over the other. Data were subjected to analysis of exponential regression. To estimate the best density the linearization curve using a logarithmic transformation was performed.

\section{Results and Discussion}

In Table 3 (2011 harvest) is shown that average infestation of thrips and aphids were not significant to crops and conventional tomato PPM. However, to whitefly and the sum of the vectors, the PPM was significant compared to Conventional. For whitefly in PPM, the average values of adults have not reached the level of action being $60 \%$ below the average obtained by conventional tillage. When summed the viruses vectors, we observed that the PPM was below the action level, unlike conventional that achieved a $56 \%$ higher rate of adults in tomato. A reduction in fly vectors population in PPM due to the use of yellow card traps around the crop reduced the use of specific insecticides to control insect vectors of viruses.
The level of infestation observed in Fig. 1, in 2011 shows that only assumed whitefly vector values greater than 1 vector/rod to the PPM and Conventional systems. For the sum of the vectors of viruses, conventional was above or equal to the action level in $80 \%$ of samples, compared to $30 \%$ to PPM. It can be seen the occurrence of population peaks even when there were no sprays, which can be attributed to climatic factors such as humidity and temperature. In the 2011 harvest, for conventional tillage, there were 14 applications of insecticides listed in Table 2, compared with 6 applications of PPM in the same season.

In Table 4 (2012 harvest) is shown that the average infestation of thrips was not significant to crops and conventional tomato PPM, no application is recommended to insect vectors. However, to aphids and whitefly vector, the PPM infestation was significant compared with the conventional one. Population reduction of aphids and whitefly vectors in PPM occurred due the use of yellow card traps around the crop, which allowed the capture of adult vectors. The average adult whiteflies number in the conventional system was $61 \%$ higher than that obtained in the PPM. When summed viruses vectors, it is observed that conventional system achieved a $63 \%$ higher rate of adult vectors in the field.

The level of infestation observed in Fig. 2 (2012 harvest) shows that only whitefly assumed values exceeding a vector/rod in both treatments. In the sum of viruses vectors, conventional was above or equal the action level in $85 \%$ of samples, versus only $40 \%$ of PPM. A whitefly was the most abundant species caught in yellow card traps. In the 2012 harvest, using conventional tillage, there were 15 insecticides applications listed in Table 2, compared with 8 PPM applications in the same harvest.

The use of traps to capture adults is allowed by a physical barrier or color. The attraction of whitefly by traps of different colors. Researches have recently studied and related that insects are lured by colors 
Table 3 Average number ( \pm SEM) of adult thrips, aphids, whitefly vectors and samples collected in tomato planting Conventional and Phytosanitary Pest Management systems (PPM) Cachoeiro de Itapemirim, 2011 harvest.

\begin{tabular}{lllll}
\hline \multicolumn{4}{c}{ Insect pests } \\
\hline Systems & thrips & aphids & whitefly & vectors \\
Conventional & $0.075 \pm 0.017 \mathrm{a}$ & $0.230 \pm 0.0371 \mathrm{a}$ & $1.175 \pm 0.141 \mathrm{a}$ & $1.495 \pm 0.168 \mathrm{a}$ \\
PPM & $0.090 \pm 0.019 \mathrm{a}$ & $0.145 \pm 0.0312 \mathrm{a}$ & $0.735 \pm 0.131 \mathrm{~b}$ & $0.955 \pm 0.157 \mathrm{~b}$ \\
\hline
\end{tabular}

Means followed by the same letter in the column do not differ by Mann-Whitney test $P \leq 0.05$.

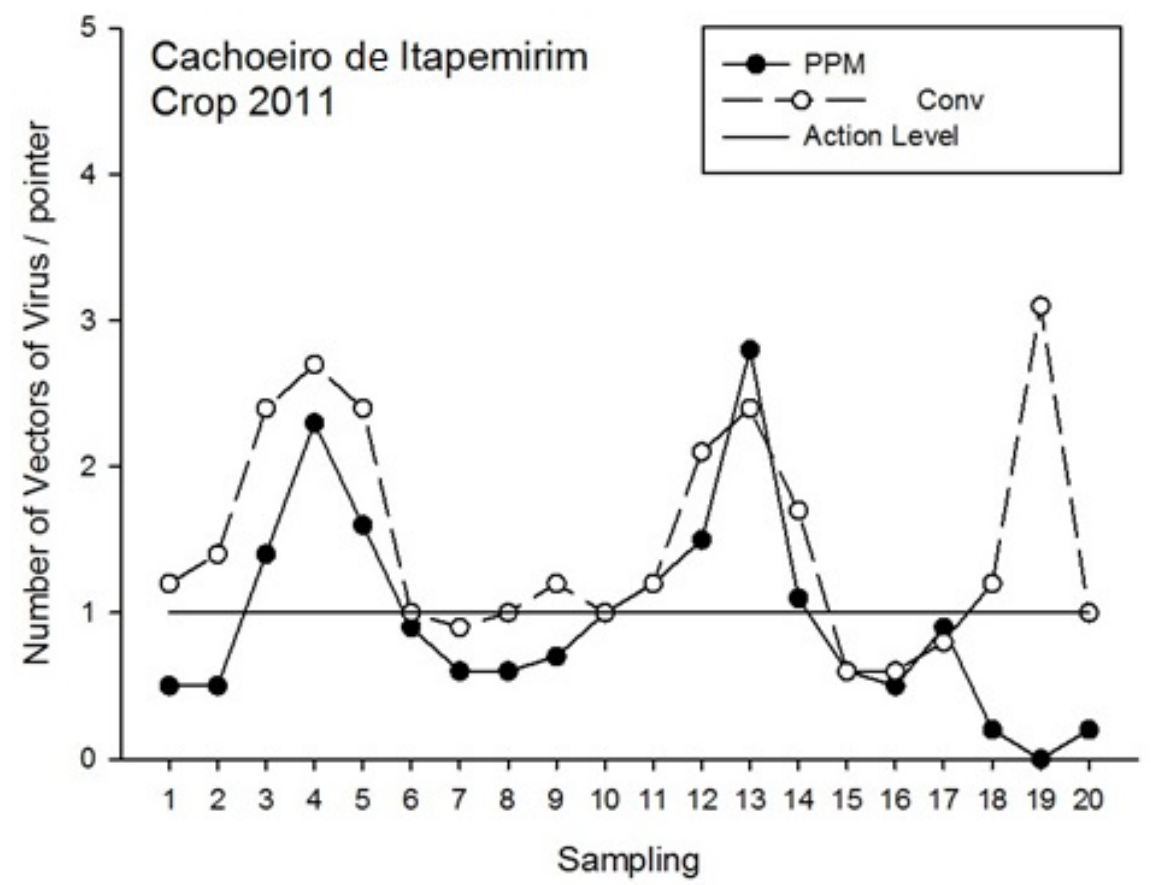

Fig. 1 Infestation of insect vectors of viruses in the 2011 index from tomato crops in conventional Phytosanitary Pest Management (PPM) in Cachoeiro de Itapemirim.

Table 4 Average number ( \pm SEM) of adult thrips, aphids, whitefly, vectors collected in tomato planting Conventional and Phytosanitary Pest Management systems (PPM) in Cachoeiro de Itapemirim, 2012 harvest.

\begin{tabular}{lllll}
\hline \multicolumn{5}{c}{ Insect pests } \\
\hline Systems & thrips & aphids & whitefly & vectors \\
\hline Convencional & $0.105 \pm 0.017 \mathrm{a}$ & $0.236 \pm 0.034 \mathrm{a}$ & $1.295 \pm 0.166 \mathrm{a}$ & $1.660 \pm 0.200 \mathrm{a}$ \\
PPM & $0.075 \pm 0.018 \mathrm{a}$ & $0.140 \pm 0.024 \mathrm{~b}$ & $0.805 \pm 0.129 \mathrm{~b}$ & $1.020 \pm 0.147 \mathrm{~b}$ \\
\hline
\end{tabular}

Means followed by the same letter in the column do not differ by the Mann-Whitney $P \leq 0.05$.

because of visual and olfactory characteristics. The high reflectance of yellow color promotes whitefly attractiveness. Studies have shown that the yellow color for traps are more attractive [11, 12]. Mainali and Lim found a reduction in whitefly number in tomato grown in greenhouses using yellow traps. Therefore, one can correlate the high incidence of catching adult whitefly in this study with the yellow color of the traps of previous studies, which could increase the cost/benefit to the producer and of the utmost importance for consumers and the environment [13].

Despite the critical period to vectors of viruses to inoculate the virus in tomato be up to 60 days from transplanting, should be taken with some care adult whiteflies in the field, as they continue sucking sap, 


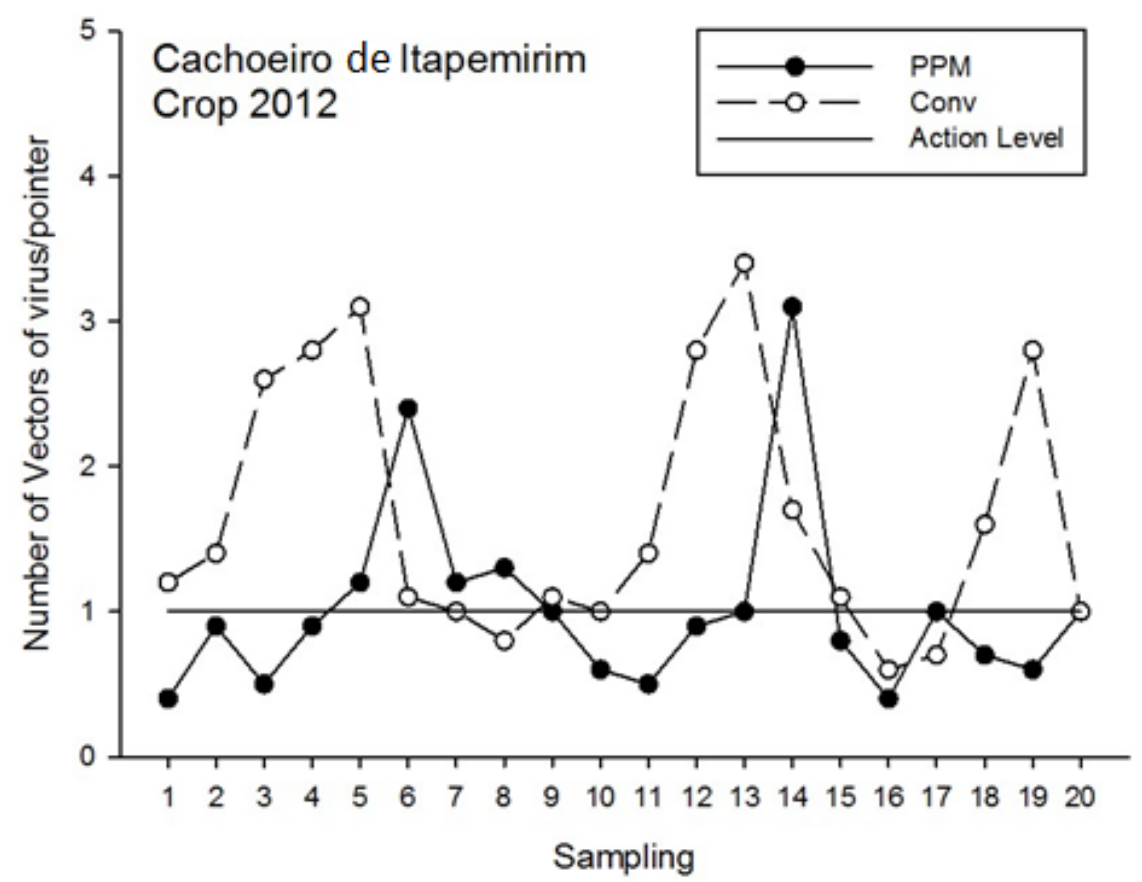

Fig. 2 Fluctuation of insect vectors of viruses population in 2012 tomato harvest in Conventional and Phytosanitary Pest Management (PPM) in Cachoeiro de Itapemirim.

injecting a toxin that causes anomalies in ripe fruits, leaving them with yellowish bands, making them depreciable to be consumed "In nature" (Fig. 3). Therefore, monitoring is required throughout the cycle to avoid significant increase of the population of vectors, which may cause considerable damage to the following crops. Another relevant factor is the wind that spreads the vectors to new crops, so the importance of having traps with traps and color if possible borders with plants that are not vectors hosts of viral diseases and/or pests of tomato.

To handle vectors of viruses in tomato, it is necessary to eliminate all vectors of host weeds before planting an early crop. It is also of great importance and puts them seedlings are still protected by the sowing anti-aphid screens to reach stronger the field, thus enduring greater pest attack. The sooner the plant is infected by viruses, more damage will be observed that will directly affect productivity.

One adult whitefly per plant is enough to cause incidence of the virus of $100 \%$ under field conditions, if such an insect is infected by some virus, may cause total losses [14]. Reported that only 0.3 adult whitefly per plant quickly spreads the virus on tomato [15]. Where tospoviruses are present, control measures must conform to the level of action indicated by the constant sampling in the field [16].

Considering this evidence, the visual attraction of insects may be used in integrated pest management in order to reduce the use of pesticides in the environment and in food. Therefore, it is important to make it an indispensable component in monitoring and management of whitefly, thrips and aphids on vegetable crops.

It can be observed in Fig. 3, the density of traps followed an exponential regression to whitefly, aphids, thrips vectors and viruses. The ideal amount of traps per plant ranked 60 plants/trap.

These data are important to a correct use of this tool on the field, it was not known how many plants/trap would be sufficient to achieve a good control of vectors of viruses. Another important factor is the ease of use by the producer and being economically viable. 


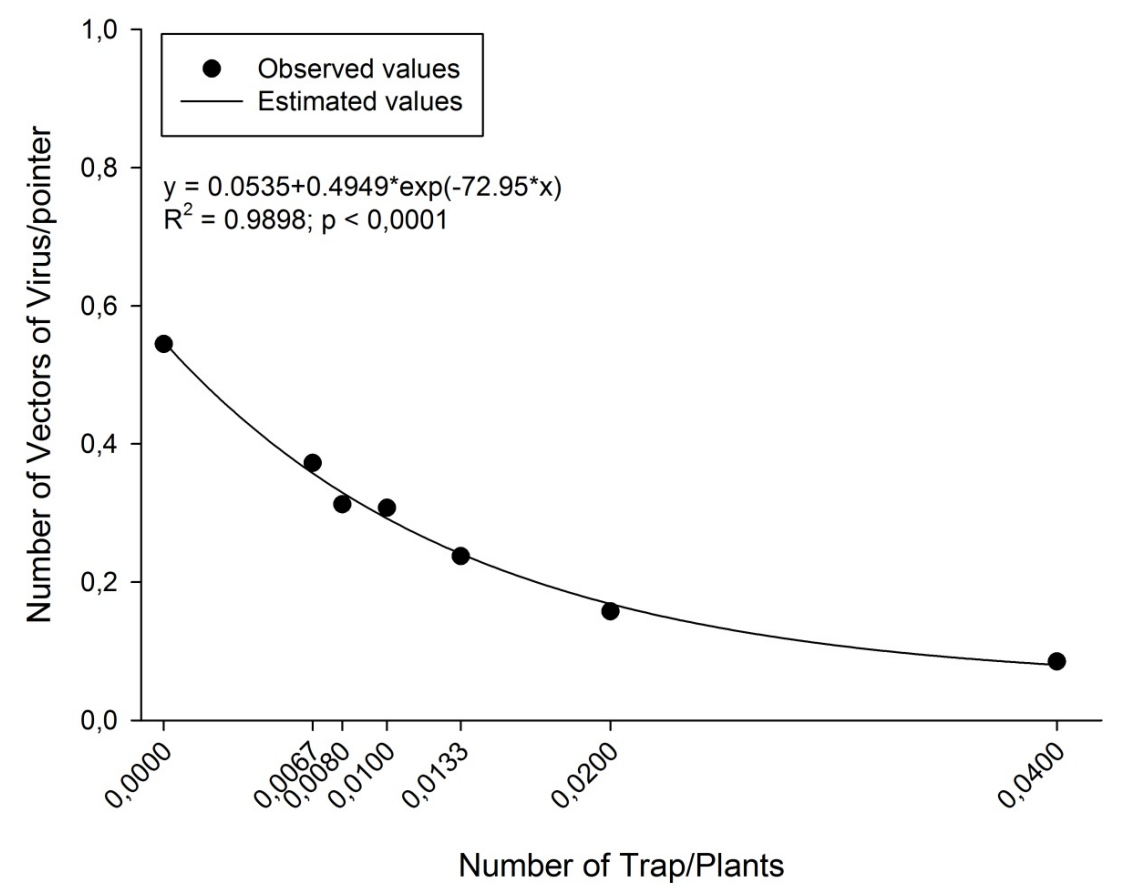

Fig. 3 Density of traps to insect vectors of plant viruses in Cachoeiro de Itapemirim.

Table 5 Cost/benefit/ha on Phytosanitary Pest Management (PPM) and Conventional (Conv.) systems in Cachoeiro de Itapemirim.

\begin{tabular}{|c|c|c|c|c|c|c|}
\hline \multicolumn{7}{|l|}{2011 harvest } \\
\hline Inseticides & $\mathrm{R} \$$ ha & PPM & Conv. & $\mathrm{R} \$ \mathrm{PPM}$ & R\$ Conv. & Saving \\
\hline Platinum Neo & 125.00 & 2 & 4 & 250.00 & 500.00 & 250.00 \\
\hline Actara & 27.00 & 1 & 2 & 27.00 & 54.00 & 27.00 \\
\hline Connect + Oberon & 186.00 & 2 & 2 & 372.00 & 372.00 & - \\
\hline Mospilan & 49.00 & 1 & 6 & 49.00 & 294.00 & 245.00 \\
\hline Sum total & & & & 698.00 & $1,220.00$ & 522.00 \\
\hline \multicolumn{7}{|l|}{2012 harvest } \\
\hline Inseticides & $\mathrm{R} \$$ ha & PPM & Conv. & $\mathrm{R} \$ \mathrm{PPM}$ & R\$ Conv. & Saving \\
\hline Platinum Neo & 125.00 & 2 & 5 & 250.00 & 625.00 & 375.00 \\
\hline Actara & 27.00 & 12 & 27.00 & 54.00 & 27.00 & \\
\hline Connect + Oberon & 186.00 & 2 & 4 & 372.00 & 744.00 & 372.00 \\
\hline Mospilan & 49.00 & 3 & 4 & 147.00 & 196.00 & 49.00 \\
\hline Sum total & & & & 796.00 & $1,619.00$ & 82.00 \\
\hline Total Crops & & & & $1,494.00$ & $2,839.00$ & $1,345.00$ \\
\hline
\end{tabular}

The Table 5 (2011 harvest), 14: 06 insecticide applications were held respectively in the conventional area and PPM to control vectors of virus diseases in tomato. In 2012 (Table 5) 15: 08 insecticide applications were held respectively in the conventional area and PPM. There was an economy in the insecticides used on PPM, R\$ 522.00 during 2011 harvest and $\mathrm{R} \$ 823.00$ in 2012, totaling an overall saving of $R \$ 1,345.00 /$ ha.

This saving only on vectors of viruses is very important, because the cost of tomato production is around R \$ 3.50/plant. One hectare holds an average of 12,000 plants, so the cost of an acre is worth $\mathrm{R} \$ 42,000.00$. 


\section{Conclusions}

Yellow card traps can be employed as a physical barrier to insect vectors of viruses;

The monitoring of plants showed that yellow card traps reduced the population of insect vectors of viruses;

A reduction in insecticides usage increases the producer profit;

The optimal trap density, as a physical barrier should be 0.017 traps/plant or 60 plants/trap.

\section{References}

[1] Filgueira, F. A. R. 2000. Tomate: a hortaliça cosmopolita, In: Filgueira, F. A. R. (ed.). Novo manual de olericultura: agrotecnologia moderna na produção e comercialização de hortaliças, 189-234, 402. Viçosa, UFV.

[2] Luz, J. M. Q., Shinzato, A. V., and Silva, M. A. D. 2007. "Comparação dos sistemas de produção de tomate convencional e orgânico em cultivo protegido." Bioscience Journal 23: 7-15.

[3] Ávila, A. C., Inoue-Nagata, A. K., Costa, H., Boiteux, L. S., Neves, L. O. Q., Prates, R. S., and Bertini, L. A. 2004. "Ocorrência de viroses em tomate e pimentão na região serrana do estado do Espírito Santo." Horticultura Brasileira 22: 655-8.

[4] Silva, A. C., and Carvalho, G. A. 2004. Manejo Integrado de Pragas. In: Alvarenga, M. A. R. (Ed.). Tomate: Produção em campo, em casa-de-vegetação e em hidroponia. Lavras, 309-66, UFLA, 400.

[5] Gallo, D., Nakano, O., Silveira Neto, S., Carvalho, R. P. L., Baptista, G. C. de, Berti Filho, E. B., Parra, J. R. P., Zucchi, R. A., Alves, S. B., Vendramim, J. D., Marchini, L. C., Lopes, J. R. S., and Omoto, C. 2002. Entomologia Agrícola. Piracicaba: FEALQ, 920.

[6] Lebedenco, A. 2006. "Eficiência de métodos de controle de pragas do tomateiro (Lycopersiconesculentum Mill.) na região de Presidente Prudente-SP". Dissertação de Mestrado, UNOESTE, Presidente Prudente.

[7] Abaurre, M. E. O. 2010. Práticas culturais. In: Instituto
Capixaba de Pesquisa, Assistência Técnica e Extensão Rural. Eds. Tomate. 133-48, Vitória: Incaper.

[8] Alves, F. R., Jesus Junior, W. C., Pratissoli, D., Polanczyk, R. A., Zanuncio Junior, J. S., Holtz, A. M., and Vianna, U. R. J. 2007. Manejo fitossanitário de doenças e plantas - novas perspectivas. In: (Ed) Jesus Junior, W. C., Polanczyk, R. A., Pratissoli, D., Pezzopane, J. E. M., Santiago, T.. Atualidades em Defesa Fitossanitária: 383-415.

[9] Gravena, S., and Benvenga, S. R. 2003. Manual prático para manejo de pragas do tomate. Jaboticabal: Gravena., 143.

[10] Gravena, S. 1991. Encontro nacional de produção $e$ abastecimento de tomate, 105-57, 2. Ed. Jaboticabal: FUNEP.

[11] Van Lenteren, J. C., and Noldus, L. P. J. J. 1990. Whitefly-plant relationships: behavioural and ecological aspects. In: Gerling, D. (ed.), 47-89. Whiteflies: their Bionomics, Pest Status and Management. Intercept Ltd, Hants, UK.

[12] Byrne, D. N., and Bellows, T. S. 1991. Whitefly Biology. Annual Review of Entomology 36: 431-57.

[13] Mainali, B. P., and Lim, U. T.. "Evaluation of Chrysanthemum Flower Model Trap to Attract Two Frankliniella thrips (Thysanoptera: Thripidae)." Journal of Asia-Pacific Entomology 11: 171-4.

[14] Hilje, L. 1997. Possibilidades para el manejo integrado del complejo mosca blanca-geminivirus en tomate, na America Central. In: Congresso Brasileiro De Entomologia, 16., Salvador. Resumos... Salvador: SEB; EMBRAPA-CNPMF, 9.

[15] Cubillo, D., Sanabria, G., and Hilje, L. 1999. Eficacia de coberturas vivas para el manejo de Bemisia tabaci como vector de geminivirus, en tomate. Manejo Integrado de Plaga (51): 10-20. Turrialba.

[16] Mattos, M. A. de A. 2001. Bemisia argentifolii Bellows \& Perring (Hemiptera: Aleyrodidae), na cultura do tomate no Submédio do Vale do São Francisco: estratégias de controle com agroquímicos, efeitos sobre a maturação irregular dos frutos, Brix, acidez, produtividade e análise do benefício/custo. Dissertação (Mestrado) - Universidade Federa Rural de Pernambuco, Recif. 